
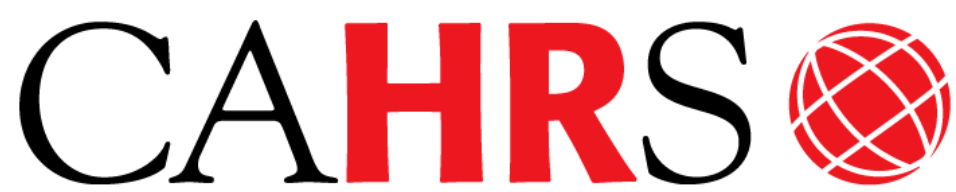

Center for Advanced Human Resource Studies

Worhing Paper gealeg
CAHRS / Cornell University 187 Ives Hall

Ithaca, NY 14853-3901 USA Tel. 607 255-9358

www.ilr.cornell.edu/CAHRS/

\title{
Desegregating HRM: A Review and Synthesis of Micro and Macro Human Resource Management Research
}

\author{
Patrick M. Wright \\ Wendy R. Boswell \\ Working Paper 02 - 11
}

CORNELL îlr school of Industrial and Labor Relations 


\title{
Desegregating HRM: A Review and Synthesis of Micro and Macro Human Resource Management Research
}

\author{
Patrick M. Wright \\ Department of Human Resource Studies \\ New York School of Industrial and Labor Relations \\ Cornell University \\ Ithaca, NY 14853-3901 \\ Wendy R Boswell \\ Department of Management \\ Lowry Mays College \& Graduate School of Business \\ Texas A\&M University \\ College Station, TX 77843-4221
}

October 18, 2002

\section{http://www.ilr.cornell.edu/cahrs}

This paper has not undergone formal review or approval of the faculty of the ILR

School. It is intended to make results of Center research available to others interested in preliminary form to encourage discussion and suggestions. 


\begin{abstract}
Since the early 1980's the field of HRM has seen the independent evolution of two independent subfields (strategic and functional), which we believe is dysfunctional to the field as a whole. We propose a typology of HRM research based on two dimensions: Level of analysis (individual/ group or organization) and number of practices (single or multiple). We use this framework to review the recent research in each of the four sub-areas. We argue that while significant progress has been made within each area, the potential for greater gains exists by looking across each area. Toward this end we suggest some future research directions based on a more integrative view of HRM. We believe that both areas can contribute significantly to each other resulting in a more profound impact on the field of HRM than each can contribute independently.
\end{abstract}

The authors wish to thank Michael Wesson, Quinetta Roberson, Christopher Collins and two anonymous reviewers for their helpful comments on an earlier draft of this paper. The first author also wishes to acknowledge that support for the preparation of this paper was provided by the Center for Advanced Human Resource Studies at Cornell University. 


\section{Desegregating HRM: A Review and Synthesis of Micro and Macro Human Resource Management Research}

Yearly reviews of Human Resource Management (HRM) appearing in Journal of Management have consistently attempted to balance the reviewing of micro, traditional, functional aspects of the field and more macro, or strategic aspects of HRM. Mahoney and Deckop's (1986) review began this dichotomization, identifying a number of trends within the field, such as a move from personnel administration to human resource management and a move from human resource planning to strategy. Three years later, Fisher (1989) further distinguished between the macro and micro wings of HRM. She noted the distinction between the concerns of top HR executives such as tying HR to strategy and dealing with strategic issues such as mergers and acquisitions, international HRM, and downsizing, and the nuts and bolts activities of operational HR managers such as selection, training, compensation, and performance appraisal. Most recently, Ferris, Hochwarter, Buckley, Harrell-Cook, and Frink (1999) explored strategic, international, and political perspectives of HRM. Wright and McMahan (1992) departed from this balanced approach by focusing solely on strategic HRM research.

While these reviews have commendably identified some of the major issues surrounding the various aspects of HRM, they have consistently segregated different aspects of the field, most notably the macro (strategic) and micro (functional) sides. It is our belief that while there is much yet to be discovered in each of these areas, the time is ripe to unify the field. Through examining the linkages between these sub-fields, we attempt to integrate the previously independent issues and concerns. The purpose of this paper is to provide a framework for identifying the intersections of macro and micro HRM research and to explore how those intersections can result in more profound research progress in the field of HRM.

Toward that end, this paper will first present a typology that delineates the various sub areas within the field of HRM. Using this framework we will then review some of the major developments within each of the sub-fields over the past few years. Finally, we will explore 
some of the exciting, revealing, and hitherto ignored research questions that come to mind as we look integratively across the various areas of HRM. Our hope is to promote a more integrative view of the field of HRM.

\section{Defining the Landscape of HRM}

In distinguishing among the various areas of HRM research, the terminology leaves something to be desired. While "strategic" HRM certainly has become part of the lexicon, one wonders what term to use for everything else. Would an accurate distinction be between strategic and non-strategic? Certainly a better classification might aid in understanding the linkages among the different areas.

The term "strategic" HRM has increased in usage and interest, albeit with little consensus regarding to what, specifically, it refers (Ferris et al., 1999). For example, Chadwick and Cappelli (1999) noted that authors have used the term "strategic" to refer to research demonstrating the impact of HRM on a strategic goal such as profitability, to strategic choices made within firms as they impact on HRM systems, or to exploring the "fit" between strategies and HRM systems. Because of the ambiguity associated with the word "strategic," we will refer to "macro" HRM as a broader, more encompassing term that reflects a more organizationally focused examination of HRM. We will use the term "micro" HRM to refer to the more functionally oriented view of HRM. To understand the various categories of research that currently exist within the realm of HRM, one must delve more deeply than this distinction alone. We propose that a useful generic approach for classifying these streams of research is to examine two relatively independent dimensions.

First and most obviously, is the level of analysis dimension (essentially the macro/micro distinction). We couch this dimension in the context of variance analysis. Kerlinger (1973) argued that research design and analysis is all about identifying and accounting for sources of variance. Our first dimension differentiates the source of variability that researchers seek to identify and explain. 
Traditionally, micro HRM research has explored the impact of HR practices on individuals. Based in foundations such as industrial/organizational psychology and industrial engineering, this vein of research largely explores how HR can increase individual productivity, quality, or satisfaction. It often entails manipulating relevant HR practices in an experimental format, and then examining the impact on individuals or assessing individuals on some characteristic (skills, abilities, attitudes, etc.) and relating the assessments to some performance measure (productivity, absenteeism, turnover). In all cases, however, the goal of the research is to identify and account for variance across individuals.

On the other hand, more recent macro HRM research examines the impact of HR practices using the organization (corporation or business unit) as the level of analysis. Most often this research assesses variables through asking an informed respondent to provide the relevant value for his/her organization. This vein of research tends to focus on the variance in relevant variables across organizations, assuming relative uniformity in the variable within the organization. In other words, the design focuses on assessing variance across organizations and then accounting for that variance in some way. In most cases variance across individuals, groups, or sometimes even jobs, is ignored, thus assuming uniformity. For instance Huselid (1995) asked about HR practices for both managerial and hourly employees. While this approach recognizes variance across two broad categories of employees, it ignores any variance within these two categories.

We note that this distinction is not entirely clear-cut. At the micro end, work groups of 6-10 people often receive research attention, and the group is treated as a unit, rather than focusing on individuals. However, in such cases, researchers tend to demonstrate that the individuals within groups share perceptions of focal constructs enough that the group can be viewed as one entity. At the macro end, some studies have examined establishments (i.e., a physical site within larger company) rather than the entire company. Thus, while one could rightly argue that there are multiple levels of analysis within the HRM literature, we view the macro area as one concerned with a unit of analysis that focuses on organization (be they 
establishment, business unit or corporate) variables, and the micro area as that focusing on individuals or small work groups with shared identity.

A second distinction within the HRM literature concerns the number of practices examined. A large number of studies have examined an individual practice (e.g., a selection technique or battery) independent of any other HR practices that might exist. When conducted by micro researchers, such research often aims at technological sophistication of a particular HR practice through demonstrating the efficacy of a particular HR technique in isolation from other HR practices (e.g., how highly a structured interview correlates with individual job performance). Within the macro literature such research attempts to demonstrate the organizational impact of a particular practice (e.g., how the use of stock options correlates with organizational profitability).

On the other hand, some recent research has focused on sets of HR practices. These research studies treat multiple HR practices as a system, whether referred to as a high performance work system (HPWS) (Huselid, 1995) or as an HR practice configuration (e.g., Delery \& Doty, 1996; Lepak \& Snell, 1999). This approach tends to assume that individual practices can complement, substitute for, or even conflict with other practices, and thus to truly examine the impact of HR practices on any variable of interest, one must examine the entire system of HR practices (Delery, 1998). As will be discussed later, significant disagreement exists as to how to combine these practices (e.g., indexes, scales, clusters, etc.), but the shared assumption is that multiple, rather than isolated, practices must be examined.

Juxtaposing these two dimensions results in the typology shown in Figure 1. In the upper left-hand quadrant we see the research examining systems of HR practices at the organizational level of analysis. We tend to see studies from the industrial relations and strategic HRM fields falling in this category (e.g., Delery \& Doty, 1996; Huselid, 1995; MacDuffie, 1995). A number of studies fall here, and the number of studies focused here seems to be increasing exponentially. 
Figure 1

A typology of HRM research

\section{Number of HRM Practices}

Multiple Single

Organization

Level of Analysis

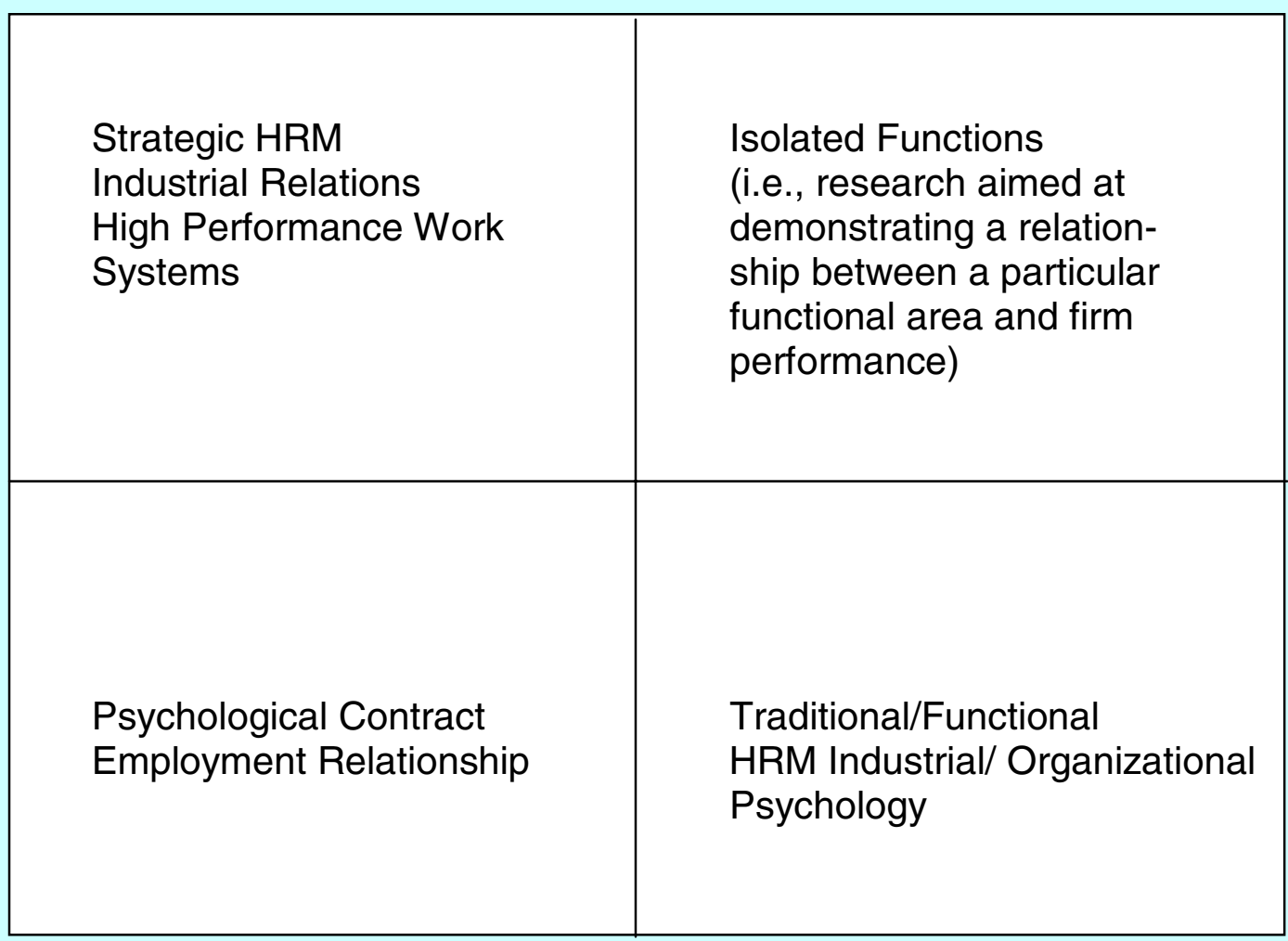


The lower right-hand quadrant reveals the area of HRM research focusing on single HR practices and their impact on individuals. This is traditionally the domain of industrial/ organizational psychology, and a large volume of research has accumulated in this area over the years.

Interestingly, the off quadrants reveal lower volumes of research. For instance the upper right quadrant examines individual practices at the organizational level of analysis. This is exemplified by Terpstra and Rozelle's (1993) study of the relationship between recruiting/ selection practices and firm performance, and by Gerhart and Milkovich's (1990) study of the relationship between compensation practices and firm performance. The lower left quadrant focuses on research exploring multiple practices at the individual level of analysis. This might be illustrated by psychological contract research, particularly that focusing on how the system of HR practices influences individual perceptions of the psychological contract (e.g., Rousseau \& Greller, 1994).

Given this typology, the next section will attempt to review some of the more significant research developments that have occurred in each of the quadrants over the past few years. We focused our review on the 1998-2000 time frame in an attempt to review the work that has appeared since the last Yearly Review of Management review of HRM (Ferris et al., 1999). However, we sometimes deviate to prior years to discuss some representative or classic studies that might provide better context to the more recent research, and include a few 2001 studies that appeared by the time we finished this review. In addition, we limited our review to the mainstream management/HRM journals. We recognize researchers in other literatures (e.g., labor economics, sociology) often examine related phenomena, but in order to keep the review to a reasonable length, we chose to focus on articles with which likely readers of JOM would be familiar. 


\section{Multiple Practice Research at the Organization Level}

The research on multiple (or systems of) HR practices at the organizational level so far has revolved around two issues: The relationship between HR practices and performance and classifications or configurations of HR practices.

HR practices and performance. Significant research attention has been devoted over the past few years to understanding how HR systems (usually referred to as High Performance Work Systems) can facilitate the accomplishment of a firm's strategic goals. Huselid's (1995) study on the relationship between HR practices and corporate financial performance serves as probably the seminal, and definitely most-cited work in this area. This was soon followed by similar research conducted by MacDuffie (1995), Delery and Doty (1996), Delaney and Huselid (1996), and Huselid, Jackson, and Schuler (1997). However, numerous researchers have built upon this foundation over the past few years to add to this literature.

Ostroff (2000) found some support for a universalistic relationship between HR practices and performance. However, more importantly she found that the relationship between clusters of HR practices and performance depended upon the business strategy of the firm. In a study of 227 trucking firms, Shaw, Delery, Jenkins, and Gupta (1998) found that HR practices explained $20 \%$ of the variance in quit rates, and $10 \%$ of the variance in discharge rates. Lam and White (1998) studied firms within 14 manufacturing industries and found that firms' HR orientations (measured by the effective recruitment of employees, above average compensation, and extensive training and development) was related to return on assets, growth in sales, and growth in stock values. Using a sample of banks, Richard and Johnson (2001) examined the impact of strategic HRM effectiveness (ratings of how effectively a variety of HR practices were performed) on a number of performance variables. They found that strategic HRM effectiveness was directly related to employee turnover and the relationship between this measure and return on equity was stronger among banks with higher capital intensity (greater investments in branches). Whitener (2001) examined the relationships among HR practices, employees' perceived organizational support, organizational commitment, and trust in management among 
a sample of credit unions. She found that HR practices, in particular developmental appraisals and equitable rewards, affect the relationship between perceived organizational support and organizational commitment.

On less positive notes, Cappelli and Neumark (2001) examined the relationships among HR practices, pay, and labor efficiency (operationalized as output per dollar spent on labor). These authors found that "high performance work practices" may raise productivity slightly, but that they also raise labor costs. Consequently, in their study, they found no impact on overall labor efficiency. Godard (2001) explored how alternative work practices impact workers. He found that moderate levels of these practices were related to increased employee attitudes such as job satisfaction, esteem, and commitment. However, he found that higher levels of adoption, particularly with increased team autonomy and responsibility, had negative effects. This negative effect was also observed for "Just-in-Time" and re-engineering programs.

This line of research has burgeoned outside the U.S. as well. Harel and Tzafir (1999) found that among public and private organizations within Israel, HR practices were related to perceived organizational and market performance. Ichniowski and Shaw (1999) compared Japanese and U.S. steel production lines. They found that while Japanese lines were more productive than U.S. lines, when U.S. lines used Japanese HR practices (problem solving teams, information sharing, extensive orientation, training, job rotation, employment security and profit sharing), they were as productive as Japanese lines. In an interesting study using data on HR reported by French firms as required by French law, d'Arcimoles (1997) found that investments in training had both an immediate and enduring effect on performance, while wages were unrelated. In a study of 428 companies in Finland, Lahteenmaki, Storey, and Vanhala (1998) found that aspects of HR practices were rarely related to company performance, but were more strongly related to future performance expectations of respondents.

Much of the recent research has been conducted in Korea. While, in a sample of 48 Korean firms, Lee and Chee (1996) found no relationship between HR practices and firm performance, Bae and Lawler (2000) did find a significant relationship between HR and firm 
performance in their sample of 138 Korean firms. Lee and Miller (1999) found some evidence for a relationship between HR practices and performance among their sample of Korean firms, but this relationship was most strongly pronounced among firms using dedicated positioning (marketing differentiation or innovative differentiation) strategies.

Finally, Guthrie (2000) found that HR practices were related to both employee retention and productivity among a sample of New Zealand firms. Interestingly, he found a disordinal interaction such that retention was positively related to productivity for firms with High Involvement Work practices, and negatively related for firms without them.

Since the mid 1990's which saw considerable research within the U.S. aimed at demonstrating the empirical relationship between HR practices and firm performance, it appears that much of this research has recently moved off-shore. Certainly the relationship is of interest to U.S. researchers, but it appears that within the U.S. more attention is now being devoted to critically evaluating past research and searching for new theoretical and empirical paradigms (e.g., Delery, 1998; Gerhart, Wright, McMahan, \& Snell, 2000; McMahan, Virick, \& Wright, 1999). However, the published research, regardless of its origin seems to provide additional support for the notion that HR practices are related to important measures of firm performance.

Classifying HR practices. One of the key consistent trends within this research has been repeated efforts to classify HR practices into categories. For instance, MacDuffie (1995) made a strong case for viewing work systems as requiring that individuals have the necessary skills and abilities, that they be motivated to do a good job, and that the system provides opportunities for them to participate. In general, three approaches have been used to classify practices: Conceptual, factor analytic, and cluster analysis.

Lawler (1986) proposed the concepts of information sharing, knowledge/skill, power (decision making), and rewards as ways to manage in a high performance/high commitment environment. Delery, Gupta, and Shaw (1997) argued that HR practices are aimed at increasing employee skills, motivation, or empowerment. Similarly, Gardner, Moynihan, Park, and Wright (2000) used the skills, motivation, and empowerment categories for classifying HR practices. 
Boudreau and Ramstad (1999) proposed the concepts of capability, opportunity, and motivation, which track quite well with categories proposed by Delery et al. and Gardner et al.

From a more factor analytic perspective, Lee and Chee (1996) used items based on Lawler's (1986) categorization of employee involvement as practices aimed at information sharing, knowledge/skill, power, and rewards. Their factor analysis results supported this fourfactor model. Huselid's (1995) factor analysis of HR practices resulted in two factors which he titled "Employee Skills and Organizational Structures" and "Employee Motivation."

A number of authors have used cluster analysis to group firms that seem to be exhibiting similar HR strategies. Ostroff (2000) conducted a cluster analysis and found 5 HRM systems. Comprehensive systems attempted to use the full range of HRM practices. Involvement systems consisted of an emphasis on practices aimed at increasing employee skills and involve workers. Traditional systems focused on practices aimed at hierarchical monitoring and control. Identification systems had low use of most HRM systems except for practices aimed at organizational identification and commitment. Finally, the None system tended to have relatively little use of HRM practices. Similarly, Becker and Huselid (1996) submitted their cross industry data to a cluster analysis and identified four HR clusters: Personnel, alignment, compensation, and high performance. Arthur's (1992) study categorized HR systems as being either "commitment" or "control" systems. Lee and Chee (1996) also submitted their results to a cluster analysis and observed four clusters: contingent payer, information sharer, weak trainer, and low involver (weak on all items).

In summary, empirical categorization schemes do not reveal consistent patterns of HR practices. However, it appears that consensus is emerging around the conceptual categorizations of employee skills (practices aimed at attracting and developing the skills of the workforce), motivation (practices that elicit high motivation), and empowerment (practices enabling employee voice and influence). Whether these conceptual categorizations will hold under empirical scrutiny remains to be seen. Delery (1998) provides a deep analysis of the basic concepts underlying the classification of HR practices from a horizontal fit perspective as 
well as their treatments empirically. However, this analysis does not clearly point to preferences for conceptual indices, factor analytic, or cluster analytic derivations. This epitomizes the need for further research in this area.

\section{Single Practice Research at the Organization Level}

As noted before, fewer studies have focused on single HR practices in research conducted at the organization level. Most often these studies have sought to demonstrate an empirical relationship between the focal HR practice and some measure of organizational effectiveness.

While not exactly a specific HR practice, Simons, Pelled, and Smith (1999) examined the diversity of top management teams among a sample of manufacturing companies. They found that job related aspects of diversity (education level, company tenure, functional background) interacted with debate to predict organizational performance. Konrad and Mangel (2000) found that Quality of Work Life (QWL) programs were more strongly associated with productivity for firms that had higher percentages of women in the workforce, and that had a higher percentage of professionals employed. Perry-Smith and Blum (2000) found that firms with extensive workfamily policies had higher self-reported performance, and that this relationship was stronger for older firms and firms with larger percentages of female employees.

Compensation also has received some attention. Montemayor (1996) found that departures from strategically-indicated pay policies resulted in lower organizational performance. Banker, Lee, Potter, and Srinivasan (1996) found that outcome-based incentives had positive impacts on sales, customer satisfaction, and profit when competition was intense, with higher percentages of upscale customers, and when supervisory monitoring was low.

Shaw, Gupta, and Delery (2001) examined the impact of pay systems on organizational performance within the concrete pipe industry. They found generally that poor performance was observed when individual incentives were paired with TQM, and high performance was observed when skill based pay was paired with TQM. 
With regard to work teams, Banker, Field, Schroeder, and Sinha (1996) found that both quality and labor productivity increase with the formation of work teams. Batt (1999) observed that participation in self-managing teams resulted in increased self-reported service quality and with sales per employee, whereas Total Quality Management did not affect performance.

In spite of the plethora of research that exists on staffing systems at the individual level, these systems have received considerably less attention at the organization level. Since Terpstra and Rozelle's (1993) study, only one other study has examined staffing systems. Koch and McGrath (1996) found that firms using more sophisticated staffing practices (planning, recruiting, and selection) had higher labor productivity.

Clearly, the bulk of macro-HRM research appearing in the management literature (excluding economics journals that often examine compensation issues) has aimed at multiple, rather than single practice studies. The single practice studies often appear driven by a motivation to prove that a certain functional area "matters." However, such studies are problematic for a few reasons. First, they ignore the potential simultaneity that might exist with other practices. For example, QWL or TQM programs are often accompanied by a variety of HR practices such as training and skill-based compensation. If these two practices tend to be implemented together, then examining the impact of one (e.g., training) without examining the other (e.g., skill based pay) might result in either a spurious relationship (i.e., it's the pay, not training that impacts performance) or at least an overestimate of the effect of the focal variable. Thus, failure to control for other practices calls into question the validity of observed effects (Ostroff \& Bowen, 2000).

In addition, such attempts seem to ignore the basic conceptual model that HRM systems, rather than an individual practices, impact employees and organizations. As we discuss later with regard to horizontal fit, while on occasion, a single practice might have a profound impact on firm performance (e.g., Continental Air Lines “on-time bonus" system), more frequently multiple HR practices influence performance. Thus, while we do not call for a 
moratorium on single practice macro research, we would argue that future studies will have greater impact if they control for other HR practices.

\section{Single Practice Research at the Individual Level}

Volumes of studies have been conducted examining the impact of a variety of single functional practices such as selection, training, recruitment, compensation, performance management, and participation/work design. We discuss the recent research in these areas below.

Selection. Personality as a predictor of employee effectiveness continues as a popular topic in the selection literature. Indeed, one could argue that there has been an explosion of dispositional research, likely due in part to the emergence of a fairly well-accepted personality framework - The "Big Five" (Goldberg, 1990). Personality has been shown to predict important work outcomes including task and contextual performance (McManus \& Kelly, 1999), leadership (Judge \& Bono, 2000), career success (Boudreau, Boswell, \& Judge, 2001; Judge, Higgins, Thoresen, \& Barrick, 1999; Seibert \& Kraimer, 2001), and employment status (De Fruyt \& Mervielde, 1999). The Big Five personality dimensions are commonly assessed, showing divergent relationships with various outcomes and often having differential effects depending on the work context investigated. For example, in studies using heterogeneous samples (Judge et al., 1999; Seibert \& Kraimer, 2001), extraversion predicted extrinsic success (e.g., salary, promotions) but was not significantly related to executive extrinsic success (Boudreau et al., 2001). Caligiuri (2000) investigated the role of personality in predicting expatriate success, finding that extraverted and agreeable expatriates were less likely to want to terminate their assignment and conscientious expatriates had more favorable performance ratings. Judge and Bono (2000) found extraversion and agreeableness positively predicted transformational leadership behavior; however, the other dimensions of the Big Five, including conscientiousness, were non-significant.

Building on the work regarding personality as an independent predictor, continuing research has examined how personality (particularly conscientiousness) works in concert with 
cognitive ability in predicting performance. Mount, Barrick, and Strauss (1999) found that though conscientiousness and cognitive ability individually were significant predictors of performance in a variety of jobs (e.g., sales, managerial), the traits did not interact to jointly predict performance. Conscientiousness and cognitive ability predicted multiple yet somewhat divergent performance criteria in Mount, Witt, and Barrick's (2000) concurrent validation study involving clerical personnel. Specifically, both traits predicted quantity and quality of work, cognitive ability predicted problem solving, and conscientiousness predicted interpersonal facilitation. Judge et al. (1999) found a strong positive effect for conscientiousness on intrinsic and extrinsic career success. They also found a positive effect for cognitive ability on extrinsic success over any effects for personality, and though cognitive ability positively correlated with intrinsic success it was non-significant in the presence of personality variables. Thus the importance of cognitive ability in predicting a variety of performance indicators has generally been upheld. The effect for conscientiousness is somewhat more equivocal in light of the nonsignificant effects found in recent research on leadership behaviors and career success.

Dispositional research is often criticized as not being theoretical (House, Shane, \& Herold, 1996). Research has begun to address this limitation by investigating possible mechanisms through which personality variables may influence work outcomes. Boudreau et al. (2001) suggested personality may influence career success indirectly through human capital and motivational variables, though results indicated that these variables mediated little of the personality effect. Judge, Bono, and Locke (2000) showed that the effect of core self evaluations (e.g., self-efficacy, locus of control) on job satisfaction is at least partially mediated by job characteristics. In other words, employees with positive core evaluations may actually hold more complex jobs or at least be predisposed to view the characteristics of their job more positively.

The increasing use of work teams and groups in organizations has led to an increased importance of research on team member traits, leadership in teams, and effective team performance (Cohen \& Bailey, 1997). Neuman and Wright (1999) found that job-specific skills, 
cognitive ability, and personality (i.e., agreeableness, conscientiousness) were important predictors of performance in their study of HR work teams. Stevens and Campion (1999) developed and validated a "teamwork" selection test that assesses interpersonal and selfmanagement KSAs. Research by Shaw, Duffy, and Stark (2000) supports the importance of preference for group work. This research found that both task and reward interdependence were positive predictors of satisfaction and that reward interdependence significantly predicted performance, lending support to the importance of a context supportive of group work.

Other recent selection research has focused on the selection interview (e.g., Barrick, Patton, \& Haugland, 2000; Cortina, Goldstein, Payne, Davison, \& Gilliland, 2000; Ganzach, Kluger, \& Klayman, 2000), test-taking motivation (e.g., Sanchez, Truxillo, \& Bauer, 2000), applicant reactions to selection systems (Ryan \& Ployhart, 2000), and adverse impact (e.g., Bobko, Roth, \& Potosky, 2000; De Corte, 1999; Ryan, Ployhart, \& Friedel, 1998). Much of this research explores the role of personality and/or cognitive ability, providing further evidence as to the importance of these constructs in the selection literature.

Training and Development. Much of the recent training and development research comes from a team perspective, focusing on performance barriers in teams, self-management, and team mental models (i.e., shared knowledge structures). Tesluk and Mathieu (1999) showed that performance-constraints such as inadequate equipment and being understaffed lead to lower group performance, while engaging in problem solving minimized these effects. Frayne and Geringer (2000) showed that self-management skill training significantly improved job performance for insurance salespeople, and that the performance effects were sustained, gradually increasing over time. Mathieu, Heffner, Goodwin, Salas, and Cannon-Bowers (2000) found that task- and team-based mental models positively predicted team processes and performance, and suggested training interventions, job rotation, and feedback programs are important for enhancing shared cognitions in workgroups.

New employee socialization and orientation also has received recent attention. Klein and Weaver's (2000) quasi-experimental study showed that employees attending a new hire 
orientation were significantly more socialized in terms of company history, goals/values, and people. Attending the orientation positively predicted subsequent affective organizational commitment, though the relation was fully mediated by organizational socialization. Chan and Schmitt (2000) modeled the relationship between individual differences, proactivity in the socialization process, and adaptation outcomes finding that seeking technical information from coworkers and coworker relationship building decreased over time, seeking technical information from supervisors and seeking referent information from coworkers remained constant, and task mastery, role clarity, and social integration increased. Allen, McManus, and Russell (1999) found that mentoring positively related to overall socialization and that socialization negatively related to both work stress and perceived help in coping with stress. However, the findings suggest that formal peer mentors serve more psychosocial than careerrelated functions.

Recruitment. It is perhaps not surprising, given the tight labor market and the increasing number of opportunities facing employees (Business Week, 1999), that a great deal of recent research focuses on the attractiveness of employers (e.g., Highhouse, Zicker, Thorsteinson, Stierwalt, \& Slaughter, 1999). Barber, Wesson, Roberson, and Taylor (1999) found that jobseekers varied on their preference for large or small firms, and search activity and recruitment sources used varied depending on these preferences (e.g., those seeking large companies engaged in more active search behaviors and were more likely to use campus services). Highhouse, Stierwalt, Bachiochi, Elder, and Fisher (1999) found that African-Americans were more likely to apply to a hypothetical job advertisement when it was identity-conscious (i.e., affirmative action) than when it was identity-blind (i.e., equal-employment opportunity). The participants also were more attracted to individual-based compensation, and reacted negatively to a job advertised as involving individual-based work coupled with a group-based performance pay system.

Recent research suggests that the information applicants receive from a company about its culture is often unrealistically positive (Cable, Aiman-Smith, Mulvey, \& Edwards, 2000). As 
noted by the authors, "the short-term benefits of beguiling applicants may be offset by subsequent turnover, poor fit, and lower commitment" (p. 1083). Phillips' (1998) meta-analysis supports this contention, finding that realistic job previews (RJPs) relate to higher performance and lower initial expectations and turnover. In their reanalysis of how RJPs operate, Hom, Griffeth, Palich, and Bracker (1999) showed that RJPs promote accurate preemployment expectations, enhancing employee attitudes and reducing withdrawal cognitions and turnover.

Kristof-Brown (2000) showed that recruiters distinguish between person-organization ( $P$ O) fit and person-job (P-J) fit, relying on different types of information when determining P-J fit versus P-O fit (i.e., KSA vs. personality and values, respectively). Each type of fit positively predicted hiring recommendations, though perceived P-J fit explained greater variance thus supporting the continued importance to organizational recruiters of hiring employees with the characteristics required for the "job."

Compensation. Rynes and Bono (2000) reviewed the micro research on pay determinants noting that task performance is not the only determinant of compensation. Indeed, recent research suggests contextual performance plays an important role (e.g., Kiker \& Motowidlo, 1999; Van Scotter, Motowidlo, \& Cross, 2000). In terms of pay outcomes, recent research has focused on incentive pay (see Jenkins, Mitra, Gupta, \& Shaw, 1998 metaanalysis). Sturman and Short (20000) proposed and explored a measure of lump-sum bonus satisfaction. Wood, Atkins, and Bright (1999) found that bonuses based on end-of-period appraisal ratings lead to setting more challenging goals but lower performance compared to bonuses based on self-set goals. Moussa (2000) found that a straight piece-rate system coupled with instructions to set hard goals resulted in the highest level of set goals. A downside to pay for performance was also recently demonstrated (Deckop, Mangel, \& Cirka, 1999). Pay for performance negatively affected organizational citizenship behavior for those employees with low value commitment. In other words, when employee and employer interests are not aligned, the "performance-pay link is the main employment exchange" (p.422) perhaps providing a disincentive for employees to engage in extra-role behaviors. 
A few recent studies have focused on employee benefits. For example, a study focusing on the mechanism through which individual differences predicted work outcomes found that the effect of personal characteristics (e.g., years of service, risk preference) on choice of retirement plans was primarily mediated by preferences (Dulebohn, Murray, \& Sun, 2000). The researchers drew on attitude theory to argue the proximal influence of employee plan preferences to retirement plan choice and that a choice is viewed positively when it is perceived as a source of benefit or reward. Using a social exchange framework, Lambert (2000) showed that perceived usefulness of work-life benefits positively predicted organizational citizenship behavior (e.g., interpersonal helping), suggesting that employees finding value in what the organization offers is particularly important for reciprocation.

Researchers have recently explored the role of pay dispersion within organizations. This line of research is likely driven in part by business-press reports of escalating CEO and top manager pay and the possible deleterious effects on employees. In his study of major league baseball players, Bloom (1999) found that greater pay dispersion was negatively related to individual and team performance but that the effect was moderated by an individual's position within the pay distribution. Specifically, more hierarchical pay negatively related to performance for people lower in the pay distribution but dispersion positively related to performance for those higher in the distribution. It appears that hierarchical pay can lead to feelings of inequity and create motivational problems. Pay fairness also has been the focus of recent research (Heneman \& Judge, 2000). For example, the relationship between skill-based pay and positive employee reactions appears to be mediated by perceived fairness (Lee, Law, \& Bobko, 1999).

Performance management. The perpetual "criterion problem" continues to receive considerable attention within the performance management literature. Micro research has increasingly recognized the more general role of employees' contributing to an organization's success, perhaps beyond specifically defined job duties. This perspective is reflected in recent research on extra-role behavior and predictors of performance that generalize across jobs. 
There has been a great deal of recent research on extra-role (contextual or organizational citizenship) behavior, arguing that contributing to an organization's strategic success means employees may need to go above and beyond responsibilities defined in their job descriptions (e.g., Lam, Hui, \& Law, 1999). Morrison and Phelps (1999) suggest that "taking charge" is an important dimension of extra-role behavior, arguing that organizations need "employees who are willing to challenge the present state of operations to bring about constructive change" (p. 403) for continued viability. Taking charge was predicted by selfefficacy, felt responsibility for bringing about change, and perceived top management openness. Other research supports the importance of perceived organizational support to both extra- and in-role behavior (Hofmann \& Morgeson, 1999), particularly for employees fearing exploitation (Lynch, Eisenberger, \& Armeli, 1999). Goodman and Svyantek (1999) found organizational culture and, more importantly, person-organization fit, predicted contextual performance. Taken together, this research highlights the importance of both contextual and individual factors in supporting important employee work behavior.

Related research argues that today's dynamic business environment necessitates the addition of adaptive performance (e.g., flexibility, tolerance for uncertainty) to extant conceptualizations of important performance dimensions (e.g., Campbell, 1999; Hesketh \& Neal, 1999). Pulakos, Arad, Donovan, and Plamondon (2000), for example, developed a multidimensional measure of adaptive employee performance, finding that many adaptive performance dimensions are critical across a variety of jobs. Worker adaptability on dimensions such as culture, work stress, and creative problem solving may be particularly important given the changing nature of work, globalization, and innovations in technology. Lepine, Colquitt, and Erez (2000) recently noted the importance of cognitive ability, openness, and low conscientiousness to adaptability.

Expanding employee job roles suggests that performance management should involve the measurement, evaluation, and development of performance beyond what is derived from the job analysis. In other words, the traditional notion that job characteristics are derived from 
the function of the job (McCormick, 1976) may be obsolete. In their recent development of a theory-based measure of employee performance, Welbourne, Johnson, and Erez (1998) identified five work-related roles and demonstrated that consideration of these multiple roles is a useful and valid approach to assessing performance. As noted, "evaluating only those work behaviors defined by the organization as related to a specific job may exhibit deficiency error" (p. 542).

Research also has begun to look beyond the cognitive processing and "accuracy" aspects of performance management, focusing more on actual changes in employee behavior (Findley, Giles, \& Mossholder, 2000) and enhanced employee attitudes and reactions (Druskat \& Wolff, 1999; Dulebohn \& Ferris, 1999; Keeping \& Levy, 2000). For example, Mayer and Davis (1999) showed that a performance appraisal system comprised of a self-appraisal, communication of expectations, and employee participation enhanced employee trust in management. Perhaps most important is the role of performance management in actually improving performance. Walker and Smither (1999) found a favorable performance effect for an upward feedback system on initially poor and moderate performers over a 5-year period. This study also found that performance improved the most for managers who met with their subordinates to discuss the feedback, supporting the importance of what managers do with the feedback they receive.

Recent research has explored the parameters of feedback system effectiveness. For example, Williams, Miller, Steelman, and Levy (1999) showed that feedback seeking in a public setting is enhanced and reactions toward the feedback more positive in a supportive environment. Nease, Mudgett, and Quinones (1999) found that self-efficacy moderated the relationship between repeated negative feedback and feedback acceptance such that individuals with high self-efficacy decreased their acceptance of feedback while this change in acceptance did not occur for those with low self-efficacy. A study on upward feedback indicates that attitudes toward the organization and the performance management system may influence the effectiveness of such systems at bringing about performance improvements (Atwater, 
Waldman, Atwater, \& Cartier, 2000). Atwater et al. also found a positive relationship between subordinate ratings of supervisors and supervisors' subsequent commitment to those subordinates.

Participation/Work Design. Recent research on work design also recognizes the changing nature of work. For example, Edwards, Scully, and Brtek (1999) proposed changing employment arrangements and work activities require measures of work that are "valid, comprehensive, and applicable across contexts" so that determinants and consequences of work attributes can be explored. Edwards et al. examined the Multimethod Job Design Questionnaire (Campion, 1988; Campion \& Thayer, 1985), and through exploratory analysis, found that the MJDQ may be best specified as a 10-factor measure of work (e.g., feedback, specialization, work conditions).

Baltes, Briggs, Huff, Wright, and Neuman (1999) meta-analyzed the effects of alternative work schedules on various work outcomes. Results indicated a favorable influence of flextime on productivity, satisfaction, and absenteeism. Compressed workweeks positively influenced satisfaction and supervisor rating of performance, but not productivity or absenteeism. Similarly, Kossek and Ozeki's (1998) meta-analysis found a strong, negative relation between work-family conflict and both job and life satisfaction.

Prior research suggests that participation positively effects employee performance and satisfaction (Locke, Alavi, \& Wagner, 1997), though the effect on performance likely depends on whether an individual possesses relevant knowledge (e.g., Scully, Kirkpatrick, \& Locke, 1995). Regarding satisfaction, Roberson, Moye, and Locke (1999) found that perceived fairness plays a role. Their research showed that procedural justice fully mediated the relation between participation and task satisfaction, suggesting that "reactions to procedures are a significant factor in determining employee satisfaction" (p. 591). Wanberg and Banas (2000) found that participating in and receiving information about a change process enhanced employee openness to workplace change. Cawley, Keeping, and Levy's (1998) meta-analysis found strong support for the importance of participation in the performance appraisal process to work 
attitudes. The importance of involvement and discretion to teams has also been noted. Kirkman and Rosen (1999) found that team empowerment (i.e., autonomy, impact, meaningfulness, potency) positively correlated with performance and attitudinal outcomes. Alper, Tjosvold, and Law's (2000) study of self-managing work teams showed that a cooperative approach to conflict resolution (e.g., emphasizing mutual goals, understanding everyone's views) enhanced conflict self-efficacy and ultimately employee effectiveness.

Certainly a plethora of single practice - individual level research exists and this body of research continues to grow. Note that this vein of research recognizes individual differences in reactions to a given HR practice, and specifically focuses on the variance associated with those differences.

\section{Multiple Practice Research at the Individual Level}

Rousseau and colleagues' research on psychological contracts represents research investigating multiple practices at the individual level. Specifically, Rousseau and Greller (1994) argue experiences within an organization, specifically HR practices, shape employee beliefs regarding the terms of the employee-organization exchange relationship (i.e., psychological contract). They further propose that aligning the various HR practices can help an organization send a consistent message to employees regarding mutual expectations. Guest (1998) proposed a similar perspective, arguing that organizational culture, HR practices and policies, and the like shape psychological contracts. It should be noted that this stream of research focuses on individual perceptions stemming from a set of practices; thus psychological contracts and related perceptions are perhaps best viewed as the linking mechanism between HR practices and individual attitudes and behaviors.

There also has been some empirical work on psychological contracts. Gundry and Rousseau (1994) explored critical events identified by new employees (e.g., casual dress code, menial work assignment) and how these events relate to the employees' perceived behavioral norms within the organization. Thomas and Anderson (1998) showed that new employees' perceptions regarding the organizations' obligations change over time, and that these changes 
result in part from acquiring new information. Robinson and Rousseau (1994) found that psychological contracts are often violated, and that this associates positively with turnover and negatively with trust and satisfaction. A related study on employer inducements (i.e., rewards for performance, job/career growth opportunities, and commitment [e.g., opportunity for input, job security]) showed the greater the discrepancy between what the employee perceived as the inducement offered and what the employer reported offering, the lower the level of satisfaction with the organization (Porter, Pearce, Tripoli, \& Lewis, 1998).

Other research has explored alternative types of employment relationships as they relate to individual employee outcomes. Tsui, Pearce, Porter, and Tripoli (1997) explored the effect of four employee-organization relationship approaches on various employee outcomes. More specifically, they investigated the balance between employer-expected employee contributions (e.g., rewards based on performance) and employer-offered inducements (e.g., recruit from within). Results indicated that the mutual investment and over-investment approaches generally associated with high levels of employee performance and more favorable attitudes compared to the quasi-spot-contract (i.e., highly circumscribed) and under-investment approaches. Similarly, Shore and Barksdale (1998) focused on employee (e.g., accept transfers) and employer (e.g., high pay) obligations, finding four types of exchange relationships (mutual high obligations, employee under-obligation, employee over-obligation, mutual low obligations). Results indicated that the mutual high obligation group had the highest levels of commitment, perceived organizational support, optimism about career, and intent to stay with the organization. These findings are consistent with macro research showing positive firm-level effects for highinvolvement/commitment work systems (e.g., Arthur, 1994; Huselid, 1995).

The dearth of research aimed at understanding how multiple (or systems) of HR practices impact individuals certainly suggest a ripe opportunity for future research. Much of the strategic HRM research assumes systems of practices impacting groups of people rather homogeneously, but given our knowledge of individual differences, this assumption is tenuous, at best. 


\section{Future Trends and Issues in HRM Research}

Having presented the typology and reviewed some of the recent developments in HRM in its context, we now turn to exploring the implications for future directions.

\section{Bridging the Macro/Micro Gulf}

As noted earlier, past yearly reviews have traditionally compartmentalized the micro and macro HRM research, virtually ignoring their interface. An integrative view of the field requires that we examine how these two areas can contribute to one another as well as the kind of interesting questions that emanate from their nexus.

Applying micro rigor to macro research. One of the most obvious places of contribution stems from the extensive research methodology and analytic techniques that have evolved within the micro research domain. While early macro research has revealed a number of interesting and provocative relationships, this emerging field can now benefit from more rigorous methodologies and techniques.

For example, much of the macro HR research relies on single respondents for assessing HR variables. Yet, within the micro HR literature, a long history of research has focused on the low interrater reliabilities that often exist when assessing relevant variables such as job performance (Viswesvaran, Ones, \& Schmidt, 1996). Micro researchers consequently seek ways to either increase the interrater reliability of their measures, and/or to correct for the effects of unreliability in their observed relationships. However, until recently, the issue of interrater reliability almost has been ignored within the macro HRM literature.

Gerhart, Wright, McMahan, and Snell (2000) found that the single rater reliability of individual HR practice items averaged about .16, and even a scale artificially constructed to maximize reliability could only reach .40 . Wright et al. (2001) presented 3 additional studies supporting concerns about the reliability of single rater measures of organizational HR practices. While we have no expectation that single rater designs will (or should) disappear, it certainly seems advisable to devote more attention in the design of studies toward finding ways to reliably measure the relevant constructs. 
In addition, the macro HR field has utilized almost exclusively cross-sectional designs. Given the potential for systematic bias in the measures of HR (Gardner, Wright, \& Gerhart, 1999), it seems that much more work needs to be done with longitudinal designs to provide more valid evidence of the causal impact of HR on performance.

Apply macro goals to micro research. Just as macro research can benefit from micro methodology, micro HRM research can learn from the overarching goals of macro research. Criticized by some as tending towards an overly managerialist orientation (Kochan, 1999), macro HRM research has tended to adopt the assumption shared by strategy researchers that organizations seek to maximize their economic performance. Innovative research by Huselid (1995) and Welbourne and Cyr (1999) both seek to demonstrate that HR somehow impacts shareholder wealth.

This by no means implies that micro HRM research ignored organizational goals or pays no attention to economic performance. Rather, the point is that over time, as researchers become more and more focused on developing a deeper understanding of a narrowly defined phenomenon (e.g., halo error), one can often lose sight of the end goal. This results in practicing HR executives seeing little value in particular research studies that might be quite rigorous, and built upon strong research streams.

Macro HRM research also generally seeks to understand HRM systems as a goal, rather than individual practices. Yet much of the micro HRM research focuses on individual HR practices. Applying macro goals to micro research also would entail broadening such research to more frequently study multiple HR practices or systems and their impact on individuals. Again, while developing a deeper understanding of how an individual practice can be designed and implemented to maximum effectiveness can be valuable, failing to study the practice in the context of its implementation within a system may lead researchers to overestimate the impact of the practice. Potentially significant insights might be gained as micro researchers expand their attention from individual practices to HR systems. 
Recognize the distinction between policies and practices. HR policies represent the firm or business unit's stated intention about the kinds of HR programs, processes, and techniques that should be carried out in the organization. HR practices consist of the actual programs, processes and techniques that actually get operationalized in the unit (Gerhart et al. 2000; Huselid \& Becker, 2000). Recognizing this distinction has a number of implications for HR research.

First, from a macro HR perspective, it highlights the need to assess the actual practices rather than the stated policies (Huselid \& Becker, 2000). Because employees can only respond to actual practices, any research attempting to demonstrate a relationship between HRM and firm performance stands on firmer ground when assessing the actual practices rather than the intended policies. This may imply that asking senior HR executives to indicate practices has less validity than asking employees themselves. And if, due to practical considerations, senior HR executives must be tapped, instructions need to clearly distinguish between the policies and practices, and emphatically request respondents to indicate the practices, and not the policies.

Second, this distinction elicits a series of interesting questions around the basic issue of why policies and practices do not converge. What happens between the decision to design and develop a 360-degree performance appraisal system and its actual implementation in the organization? Why is it that applicant scores from the most technically complex selection batteries are often ignored by decision-makers? How can we be sure that employees are attending the right kinds of training conducted with the most effective learning techniques? These questions reveal gaps between the formulation and implementation of HR practices, the causes of which we know very little (Wright \& Snell, 1998).

Third, this distinction should encourage greater specificity in macro measures of HR practices. Micro HR research has focused intensely on creating the most technically effective HR practices. Significant volumes of research data exist demonstrating the efficacy of practices such as structured interviewing, behavior modeling training, and 360 degree performance appraisal. Ostroff (2000) notes that much macro HRM ignores these technically specific 
distinctions in favor of more broadly stated practice items such as "What percentage of employees undergo formal performance appraisals?" or "How many hours of training, on average, do employee receive each year?" This lack of convergence between what we know to be technically sophisticated HR practices based on micro literature and generic measures used in macro research has been criticized elsewhere (Ferris et al., 1999; Wright \& Sherman, 1999). While researchers have continued to improve upon their measures such as moving from "employment tests" to "validated employment tests" (Huselid \& Becker, 2000), there is still much work to be done in developing macro HR practice measures that more accurately reflect our knowledge of best in class micro HR practices.

Recognize variance in HR practices within organizations. As noted previously, much of the macro HRM research empirically assumes invariability in HR practices across large groups of jobs within organizations. On the other hand, micro HRM research has been consistently more focused on studying individuals within particular jobs (especially in the areas of selection and training). These researchers, as opposed to their macro colleagues fully recognize the need for job specific HRM practices.

The macro view is both naïve and potentially detrimental to the development of the field. Conceptually, Lepak and Snell (1999) pointed out the naiveté of this approach and Lepak, Takeauchi and Snell (in press) empirically demonstrated that firms manage different employee groups differently. Failing to recognize this results in flawed analyses and interpretations of existing results. For instance, if different job groups have vastly different HR practices, yet respondents are asked to provide an assessment that aggregates across these job groups the researcher has no idea what $\mathrm{s} /$ he is obtaining. This might impact the ability to identify consistent clusters of HR practices if the clusters exist within job groups but are masked when aggregating across job groups.

Thus, macro research would be better served by focusing on either key/core jobs in any given study, or at least attempting to assess practices for more coherent job groups than simply managerial vs. hourly. Focusing on key/core jobs might be a useful approach for within industry 
studies as exemplified by Delery and Doty (1996) or MacDuffie (1995). On the other hand, in across industry studies, researchers could attempt to assess practices relative to the nine different job categories for which the Equal Employment Opportunity Commission requires reporting demographic information. This would provide for much clearer understanding of HR configurations and variations.

Linking employees to the firm's strategy. The premise behind much of the macro HRM research is that organizational processes should be properly aligned to produce synergy and compatibility in organizational direction thus helping to support strategic success (Cappelli \& Singh, 1992). However, it is equally important to consider the degree to which the actual human resources (i.e., employees) are aligned with and contributing to the organization's strategic goals. As discussed by Boudreau and Ramstad (1999, 2000), HR practices support employee capability, opportunity, and motivation to enact those behaviors critical for accomplishing key business processes and strategic success, yet we know little about translating business strategy into individual employee perceptions and behaviors.

Although we know little about the causes, processes, or consequences of strategically aligning employees, the importance of this issue is not new (e.g., Ulrich, 1998; Ulrich \& Lake, 1991; Wright \& McMahan, 1992). However, the literature has generally been at the conceptual level, arguing the importance of employee alignment with the organization's strategy. When empirical, it often proceeds to focus solely on the role of HRM practices in achieving alignment. Research by Gratton, Hope-Hailey, Stiles, and Truss (1999), for example, discussed the challenges and processes underlying the alignment of individual behaviors and business strategy. They proposed a model illustrating the link between organizational strategy and individual performance and discussed where the linkages were strongest among participant organizations. The research showed that though clear objectives were set, workforce development was often weakly linked to business strategy. Further, the companies generally were focused on short-term people strategies rather than longer-term processes. 
Boswell (2000) argued that employee "line of sight" to an organization's strategic objectives is imperative for an organization to attain its strategic objectives and ultimately be successful. This research found support for the importance of employees understanding an organization's strategy and, more importantly, how to contribute to its strategic success and to various work outcomes (e.g., attitudes, reduced job strain). Important questions to consider in future research might include: "Do employees see a coherent organizational strategy?" "How can strategic employee alignment be supported?" "Does redundancy matter?" "When is strategic employee alignment most important?" Answering these questions will likely require integration of the micro and macro literatures and processes.

Conduct multi-level research. One of the major macro/micro distinctions seems to be that the research tends to be mutually exclusive in that either the study focuses on the individual or the organizational level of analysis (Ostroff \& Bowen, 2000). This has, in large part, been due to practical considerations. When focused on the individual level of analysis, researchers can gain access relatively easily to many individuals within one organization, but not across more than one organization. When cross-organizational research is designed, researchers find it easier to identify one or a small number of respondents, but not a large number of internal respondents across multiple organizations. In addition to the access issue, multi-level research has been limited by the statistical techniques available to researchers.

Recent developments, however, might enable future research to better assess multilevel issues. For instance, standardized surveys conducted by consulting firms such as Gallup (Buckingham \& Coffman, 1999) or Fortune's "Best Companies to Work For" survey process are generating data with large numbers of internal employee respondents across large numbers of organizations. While these data have yet to make it into the academic literature, they certainly can provide much deeper and more fruitful information towards integrating macro and micro wings of HRM research.

Researchers need not rely solely on consulting firms for such data. Increasingly firms may be amenable to conducting research across sites in order to gain an understanding of the 
determinants of high versus low performing units. For example, Gardner et al. (2000) collected HR practice and employee attitude data on 6 jobs across 33 business units within one company. This data enabled them to examine the relationships among HR practices, employee attitudes, and other variables at the individual, job, and business unit levels of analysis.

In addition, researchers are beginning to learn and use more complex statistical techniques such as repeated measures regression (Cohen \& Cohen, 1983; Hollenbeck, Ilgen, \& Sego, 1994; Koslowski \& Klein, 2000) and Hierarchical Linear Modeling (Hofmann, 1997).

These techniques enable researchers to simultaneously tease out individual, group, and organizational level effects. We expect that as more multi-level data sets become available and researchers become better versed in multi-level statistical techniques, we will see the beginning of a breakdown of the macro/micro gulf.

Finally, in addition to multi-level empirical research, the field also can benefit from further development of multi-level conceptual and theoretical modeling. Ostroff and Bowen (2000) present the first attempt at developing a rather comprehensive conceptual model of how HR practices impact firm performance using a multi-level model. This effort exemplifies the kind of thinking that must take place over the next few years in order to move the field toward a much deeper understanding of the phenomena we study.

\section{Integrating Single and Multiple HR practices}

The distinction between research investigating single versus multiple HR practices similarly requires integration in order to advance the field. Mahoney and Deckop (1986) in their review noted that each of the functional areas of HRM had evolved from different disciplines. For instance they wrote:

Employee compensation was viewed as a market phenomena by labor economists and as a reward influencing individual motivation by industrial psychologists. Employee selection was approached as an application of psychometric classification and prediction. Employee training and development was viewed as the application of learning theory (p. 235). 
They, along with many others (Delery \& Doty, 1996; Ferris et al. 1999; Huselid, 1995; Wright \& McMahan, 1992; Wright \& Snell, 1991) have called for understanding what distinguishes a group of independent HR practices from a coherent HR strategy. The implications of this integrative approach are discussed below.

Understanding and assessing horizontal fit. Wright and McMahan (1992) argued that one aspect of strategic HRM consisted of creating a horizontal fit among the various HR practices such that they complemented, rather than competed with one another. This concept also has been referred to as "internal alignment” (Becker \& Gerhart, 1996; Huselid, 1995).

Interestingly, researchers have taken different approaches to thinking about horizontal fit. For example, Mahoney and Deckop (1986) argued that Kerr's (1954) model of labor market structure (job/craft structure, organizational career, or unstructured market) provided a framework for developing consistent clusters of HR practices. Other authors have hypothesized clusters of HR practices based on strategy type (Schuler \& Jackson, 1987; Wright \& Snell, 1991), employment relationship (Lepak \& Snell, 1999), or internal career ladder (Delery \& Doty, 1996). Each of these efforts attempted to conceptually develop typologies of HR practices that should fit with each other.

On the other hand, some authors have attempted to empirically derive clusters of HR practices that might constitute a "horizontal fit." In an early effort, Arthur (1992) examined HR practices within steel mini-mills. After gathering data from 38 mini-mills, he subjected the HR practice measures to a cluster analysis. While his initial analysis revealed six clusters, he eventually combined them into two basic types: commitment versus control HR systems. As previously discussed, Ostroff (2000) observed five clusters of HR practices, and Becker and Huselid (1996) identified four HR clusters.

It is important to note in light of the discussion above, that virtually all of the conceptual and empirical efforts to identify horizontally aligned HR practices have used generic HR practices such as "pay for performance" or "valid employment tests." These approaches assume that the generic practices should differ across organizational or employment types such that 
practices $A, B$, and $C$, should be observed for one system and practices $D, E$, and $F$ for another. While intuitively appealing, the research has failed so far to observe consistent differences that can form the basis for a stable typology.

Another approach to horizontal fit, however, deals not with the practices themselves, but rather, the outcomes the practices seek to elicit. Wright (1998) argued that the most important type of horizontal fit among HR practices to organizations would be when the practices all promote the same organizationally relevant outcomes. For example, for a firm seeking to compete through customer service, horizontal fit among the HR practices would exist when the selection system attracts and selects people with high levels of customer service attitudes and skills, when the reward system rewards those who serve customers, and when training provides skills that enable employees to effectively serve customers. In fact, recent emphasis on competency models provides a basic framework for creating horizontal fit. Such models identify a relevant set of behavioral competencies, and then HR practices can be designed to complementarily promote the selection and development of those competencies in individuals.

Needless to say, the issue of horizontal fit among HR practice has not been solved.

Future research has a number of avenues at its disposal to attempt to address what horizontal fit is, how it is developed, and how it can be measured.

Aggregating practices empirically. Delery (1998) presented a valuable overview regarding the aggregation of multiple HR practices in empirical research. He noted that researchers can view practices as being either additive or interactive. Additive views imply that all the practices have independent non-overlapping effects on the outcomes. Interactive views can result in two different types of relationships. First, HR practices can be seen as "substitutes" where either practice alone results in positive outcomes but adding one practice to another results in no incremental benefit. Second, some suggest that HR practices can have "synergy" effects. Positive synergy would exist when multiple practices together result in greater positive impact than the sum of the effects of individual practices. Negative synergy would exist where 
the combination of practices results in lower impact than the sum of the individual practice effects.

These conceptualizations of the impact of HR practices have important implications for the actual aggregation procedures. Delery (1998) notes that scales assume that items (practices) are measuring an underlying construct while indexes are measures of the level of a construct. He suggests that most research on HR practices should use an index, rather than a scale approach, because there is seldom an underlying construct across HR practices and the practices may often be substitutable. He also discusses the use of and problems with cluster analysis approaches to identifying firms with similar HR system types. Finally he notes alternative approaches to aggregation such as using discrepancies from an a priori defined system of practices or the use of individual practices and their interactions to capture synergistic effects. Clearly, researchers must pay more attention to aggregation issues both conceptually and empirically.

Identifying employee perceptions and reactions. As previously noted, recent research seems to suggest variance in individual's perceptions of HR practices in organizations (Gerhart et al., 2000, Gerhart, Wright et al., 2000; Wright et al., 2001). Interestingly, we know very little regarding what causes employees perceptions to differ so substantially.

Ostroff and Bowen (2000) present one attempt toward explaining this issue by their introduction of the construct of HR system strength. They suggest that strong HR systems create social structures with little ambiguity regarding organizational goals and routines (i.e., climate perceptions) and the exchange between the employee and employer (i.e., psychological contract beliefs). They propose a number of characteristics that determine HR system strength, including visibility (are HR processes and outcomes shared with employees?), clarity (is the information easily understandable?), acceptability (do employees buy into the system?), consistency of administration (are practices uniformly applied across employees and across time?), effectiveness of administration (do practices do as designed?), internal consistency (i.e., 
the horizontal fit), and intensity (how much time and effort is devoted to implementing practices?).

This description of HR system strength can go far to help the field begin to both better understand and define the concept of horizontal fit, as well as to delineate the processes through which HR practices can impact firm performance. We often hear of organizations that attempted to copy an HR practice or set of practices from a successful organization, only to find that the copied practices did not result in the same beneficial outcomes. Given that employee perceptions serve as the first link between HR practices and any outcomes, it seems important to better define the aspects of HR systems that might result in divergent perceptions. The Ostroff and Bowen (2000) effort goes quite far in identifying these aspects, and certainly serves as a foundation for a whole set of future studies. 


\section{Conclusion}

The field of HRM has evolved significantly over the past $90-100$ years. The birth of the strategic part of HRM occurred barely 20 years ago (Wright, 1998). Yet, since that time, the traditional, functional, micro, and strategic macro sides of HRM have developed in parallel, yet independent paths. Micro HRM research has resulted in technically sophisticated and demonstrably effective specific HR practices such as structured interviewing, cognitive ability testing, 360 degree performance appraisal, behavior modeling training, and a plethora of incentives such as gainsharing, profit sharing, stock options, and bonuses. Macro HRM research has demonstrated that organizations implementing more of a set of generic HR practices (e.g., tests, appraisals, training) tend to outperform those implementing fewer of those practices.

Each of these areas has progressed, yet each has far to go. We believe that the existing parallel lines of research must soon redirect toward intersecting in order to maximize the impact of HRM on organizational effectiveness. Macro HRM research can surely benefit from the rigor and knowledge produced within the micro field. Similarly, micro research will surely profit from recognizing the systemic, organizational context within which individual practices exist. Researchers who focus on integrating these areas of HRM will more profoundly impact the future of our field than those who aim toward dividing them. 


\section{Author Bio's}

Patrick M. Wright received his MBA and Ph.D. from the College of Business Administration at Michigan State University in 1988. Pat is currently Professor of Human Resource Studies in the School of ILR at Cornell University. His research interests focus primarily on how firms use people as a source of competitive advantage and the role HR functions and practices play in creating such advantage. He has published in Academy of Management Journal, Academy of Management Review, Personnel Psychology, Strategic Management Journal, Journal of Applied Psychology, and Organizational Behavior and Human Decision Processes among others. He currently serves on six editorial boards including Personnel Psychology and Journal of Management.

Wendy R. Boswell received her Ph.D. in Human Resource Studies from the School of Industrial \& Labor Relations at Cornell University in 2000 . She is an assistant professor in the Department of Management, Lowry Mays College and Graduate School of Business, Texas A\&M University. Her research interests include employee attraction and retention, strategic employee alignment, work-related stress, and executive job search. Her work appears in Journal of Applied Psychology, Human Resource Management, Journal of Vocational Behavior, Personnel Psychology, and Journal of Business \& Psychology. 


\section{References}

Allen, T. D., McManus, S. E., \& Russell, J. E. A. 1999. Newcomer socialization and stress: Formal peer relationships as a source of support. Journal of Vocational Behavior, 54: 453-470.

Alper, S., Tjosvold, D., \& Law, K. S. 2000. Conflict management, efficacy, and performance in organizational teams. Personnel Psychology, 53: 625-642.

Arthur, J. B. 1992. The Link Between Business Strategy and Industrial Relations Systems in American Steel Minimills. Industrial \& Labor Relations Review, 45: 488-506.

Arthur, J. B. 1994. Effects of human resource systems on manufacturing performance and turnover. Academy of Management Journal, 37: 670-687.

Atwater, L. E., Waldman, D. A., Atwater, D., \& Cartier, P. 2000. An upward feedback field experiment: Supervisors' cynicism, reactions, and commitment to subordinates. Personnel Psychology, 53: 275-297.

Bae, J., \& Lawler, J. J. 2000. Organizational and HRM strategies in Korea: Impact on firm performance in an emerging economy. Academy of Management Journal, 43: 502-517.

Baltes, B. B., Briggs, T. E., Huff, J. W., Wright, J. A., \& Neuman, G. A. Flexible and compressed workweek schedules: A meta-analysis of their effects on work-related criteria. Journal of Applied Psychology, 84: 496-513.

Banker, R. D., Field, J. M., Schroeder, R. G., \& Sinha, K. K. 1996. Impact of work teams on manufacturing performance: A longitudinal field study. Academy of Management Journal, 39: 867-890.

Banker, R. D., Lee, S., Potter, G., \& Srinivasan, D. 1996. Contextual analysis of performance impacts of outcome-based incentive compensation. Academy of Management Journal, 39: $920-948$.

Barber, A. E., Wesson, M. J., Roberson, Q. M., \& Taylor, M. S. 1999. A tale of two job markets: Organizational size and its effects on hiring practices and job search behavior. Personnel Psychology, 52: 841-867.

Barrick, M. R., Patton, G. K., \& Haugland, S. N. 2000. Accuracy of interviewer judgements of job applicant personality traits. Personnel Psychology, 53: 925-951.

Batt, R. 1999. Work organization, technology, and performance in customer service and sales. Industrial \& Labor Relations Review, 52: 539-564.

Becker, B., \& Gerhart, G. 1996. The impact of human resource management on organizational performance: Progress and prospects. Academy of Management Journal, 39: 779-801.

Becker, B. E., \& Huselid, M. A. 1996. Methodological issues in cross-sectional and panel estimates of the human resource-firm performance link. Industrial Relations, 35: 400422.

Bloom, M. 1999. The performance effects of pay dispersion on individuals and organizations. Academy of Management Journal, 42: 25-40.

Bobko, P., Roth, P. L., \& Potosky, D. 1999.Deviation and implications of a meta-analytic matrix incorporating cognitive ability, alternative predictors, and job performance. Personnel Psychology, 52: 561-589.

Boswell, W. R. 2000. Aligning employees with the organization's strategic objectives: Out of "line of sight," out of mind. Unpublished Doctoral Dissertation.

Boudreau, J. W., Boswell, W. R., \& Judge, T. A. 2001. Executive career success in the U.S. and Europe: Effects of personality. Journal of Vocational Behavior, 58: 53-81.

Boudreau, J. W., \& Ramstad, P. M. 1999. Human resource metrics: Can measures be strategic? In P. Wright, L. Dyer, B, J. Boudreau, and G. Milkovich, (Eds.), Strategic human resources management in the twenty-first century. Supplement 4 to G.R. Ferris (Ed.), Research in personnel and human resource management, 75-98. Stanford, CT: JAI Press. 
Boudreau, J. W., \& Ramstad, P. M. 2000. Counting what counts: HC BRidge as a guide to strategic human resource management. Working paper.

Buckingham, M., \& Coffman, C. 1999. How great managers develop top people. Workforce, 78: 102-104.

Business Week. 1999, November 29. Labor Markets in the New Economy. Staff report, 242.

Cable, D. M., Aiman-Smith, L., Mulvey, P. W., \& Edwards, J. R. 2000. The sources and accuracy of job applicants' beliefs about organizational culture. Academy of Management Journal, 43: 1076-1085.

Caligiuri, P. M. 2000. The big five personality characteristics as predictors of expatriate's desire to terminate the assignment and supervisor-rated performance. Personnel Psychology, 53: $67-88$.

Campbell, J. P. 1999. The definition and measurement of performance in the new age. In D. R. Ilgen \& E. D. Pulakos (Eds.), The changing nature of performance: Implications for staffing, motivation, and development: 399-430. San Francisco: Jossey-Bass.

Campion, M. A. 1988. Interdisciplinary approaches to job design: A constructive replication with extensions. Journal of Applied Psychology, 73: 467-481.

Campion, M. A., \& Thayer, P. W. 1985. Development and field evaluation of an interdisciplinary measure of job design. Journal of Applied Psychology, 70: 29-43.

Cappelli, P. \& Newmark, D. 2001. Do "high performance" work practices improve establishment level outcomes? Industrial and Labor Relations Review, 54: 737-775.

Cappelli, P., \& Singh, H. 1992. Integrating strategic human resources and strategic management. In D. Lewin, O. S. Mitchell, \& P. Sherer (Eds.), Research Frontiers in Industrial Relations and Human Resources, 165-192. Madison, WI: Industrial Relations Research Association.

Cawley, B. D., Keeping, L. M., \& Levy, P. E. 1998. Participation in the performance appraisal process and employee reactions: A meta-analytic review of field investigations. Journal of Applied Psychology, 83: 615-633.

Chadwick, C., \& Cappelli, P. 1999. Alternatives to generic strategy typologies in strategic human resource management. In P. Wright, L. Dyer, J. Boudreau, \& G. Milkovich (Eds.), Strategic human resources management in the twenty-first century. Supplement 4 to G.R. Ferris (Ed.), Research in personnel and human resource management, 1-29. JAI Press.

Chan, D., \& Schmitt, N. 2000. Interindividual differences in intraindividual changes in proactivity during organizational entry: A latent growth modeling approach to understanding newcomer adaptation. Journal of Applied Psychology, 85: 190-210.

Cohen, J., \& Cohen, P. 1983. Applied multiple regression/correlation analysis for the behavioral science. Hillsdale, NJ: Lawrence Erlbaum Associates.

Cohen, S. G., \& Bailey, D. E. 1997. What makes teams work: Group effectiveness research from the shop floor to the executive suite. Journal of Management, 23: 239-290.

Cortina, J. M., Goldstein, N. B., Payne, S. C., Davison, H. C., \& Gilliland, S. W. 2000. The incremental validity of interview scores over and above cognitive ability and conscientiousness score. Personnel Psychology, 53: 325-351.

d'Arcimoles, C. H. 1997. Human resource policies and company performance: A quantitative approach using longitudinal data. Organization Studies, 18: 857-874.

De Corte, W. 1999. Weighing job performance predictors to both maximize the quality of the selected workforce and control the level of adverse impact. Journal of Applied Psychology, 84: 695-702.

Deckop, J. R., Mangel, R., \& Cirka, C. C. 1999. Getting more than you pay for: Organizational citizenship behavior and pay-for-performance plans. Academy of Management Journal, 42: 420-428.

De Fruyt, F., \& Mervielde, I. 1999. RIASEC types and big five traits as predictors of employment status and nature of employment. Personnel Psychology, 52: 701-727. 
Delaney, J. T., \& Huselid, M. A. 1996. The impact of human resource management practices on perceptions of organizational performance. Academy of Management Journal, 39: 949969.

Delery, J. E. 1998. Issues of fit in strategic human resource management: Implications for research. Human Resource Management Review, 8: 289-309.

Delery, J. E., \& Doty, D. H. 1996. Modes of theorizing in strategic human resource management: Tests of universalistic, contingency, and configurational performance predictions. Academy of Management Journal, 39: 802-835.

Delery, J. E., Gupta, N., \& Shaw, J. D. 1997. Human resource management and firm performance: A systems perspective. Paper presented at the 1997 Southern Management Association Meeting, Atlanta, GA.

Druskat, V. U., \& Wolff, S. B. 1999. Effects and timing of developmental peer appraisals in selfmanaging work groups. Journal of Applied Psychology, 84: 58-74.

Dulebohn, J. H., \& Ferris, G. R. 1999. The role of influence tactics in perceptions of performance evaluations' fairness. Academy of Management Journal, 42: 288-303.

Dulebohn, J.H., Murray, B., \& Sun, M. 2000. Selection among employer-sponsored pension plans: The role of individual differences. Personnel Psychology, 53,405-432.

Edwards, J. R., Scully, J. A., \& Brtek, M. D. 1999. The measurement of work: Hierachical representation of the Multimethod Job Design Questionnaire. Personnel Psychology, 52: 305-334.

Ferris, G. R., Hochwarter, W. A., Buckley, M. R., Harrell-Cook, G., \& Frink, D. D. 1999. Human resources management: Some new directions. Journal of Management, 25: 385-415.

Findley, H. M., Giles, W. F., \& Mossholder, K. W. 2000. Performance appraisal process and system facets: Relationships with contextual performance. Journal of Applied Psychology, 85: 634-640.

Fisher, C. D. 1989. Current and recurrent challenges in HRM. Journal of Management, 15: 157180.

Frayne, C. A., \& Geringer, J. M. 2000. Self-management training for improving job performance: A field experiment involving salespeople. Journal of Applied Psychology, 85: 361-372.

Ganzach, Y., Kluger, A. N., \& Klayman, N. 2000. Making decisions from an interview: Expert measurement and mechanical combination. Personnel Psychology, 53: 1-20.

Gardner, T., Wright, P. \& Gerhart, B. 1999. Mental models of HR's impact on firm performance. Impact on validity and reliability of estimates. Paper presented at the Academy of Management Meeting, Chicago, IL.

Gardner, T. M, Moynihan, L. M., Park, H. J., \& Wright, P. M. 2000. Unlocking the black box: Examining the processes through which human resource practices impact business performance. Paper presented at the Academy of Management Meeting, Toronto.

Gerhart, B., \& Milkovich, G. T. 1990. Organizational differences in managerial compensation and financial performance. Academy of Management Journal, 33: 663-691.

Gerhart, B., Wright, P. M., \& McMahan, G. C. 2000. Measurement error in research on the human resources and firm performance relationship: Further evidence and analysis. Personnel Psychology, 53: 855-872.

Gerhart, B., Wright, P. M., McMahan, G. C., \& Snell, S. A. 2000. Measurement error in research on human resources and firm performance: How much error is there and how does it influence effect size estimates? Personnel Psychology, 53: 803-834.

Godard, J. 2001. High performance and the transformation of work? The implications of alternative work practices for the experience and outcomes of work. Industrial and Labor Relations Review, 54: 776-805.

Goldberg, L. R. 1990. An alternative "description of personality": The Big-Five factor structure. Journal of Personality and Social Psychology, 59: 1216-1229.

Goodman, S. A., \& Svyantek, D. J. 1999. Person-Organization Fit and Contextual Performance: Do Shared Values Matter? Journal of Vocational Behavior, 55: 254-275. 
Gratton, L., Hope-Hailey, V., Stiles, P., \& Truss, C. 1999. Linking individual performance to business strategy: The people process model. Human Resource Management, 38: 1731.

Guest, D. E. 1998. Is the psychological contract worth taking seriously? Journal of Organizational Behavior, 19: 649-664.

Gundry, L. K., \& Rousseau, D. M. 1994. Critical incidents in communicating culture to newcomers: The meaning is the message. Human Relations, 47: 1063-1088.

Guthrie, J. P. 2000. High involvement work practices, turnover and productivity: Evidence from New Zealand. Academy of Management Journal.

Harel, G. H., \& Tzafrir, S. S. 1999. The effect of human resource management practices on the perceptions of organizational and market performance of the firm. Human Resource Management, 38: 185-199.

Heneman, H. G., \& Judge, T. A. 2000.Compensation attitudes. In S. Rynes \& B. Gerhart (Eds.), Compensation in Organizations, 61-103. San Francisco, CA: Jossey-Bass Inc.

Hesketh, B., \& Neal, A. 1999. Technology and performance. In D. R. Ilgen \& E. D. Pulakos (Eds.), The changing nature of performance: Implications for staffing, motivation, and development: 21-55. San Francisco: Jossey-Bass.

Highhouse, S., Stierwalt, S. L., Bachiochi, P., Elder, A. E., \& Fisher, G. 1999. Effects of advertised human resource management practices on attraction of African American applicants. Personnel Psychology, 52: 425-442.

Highhouse, S., Zicker, M. J., Thorsteinson, T. J., Stierwalt, S. L., \& Slaughter, J. E. 1999. Assessing company employment image: An example in the fast food industry. Personnel Psychology, 52: 151-172.

Hofmann, D. A. 1997. An overview of the logic and rationale of hierarchical linear models Journal of Management (Special Issue: Focus on hierarchical linear modeling), 23: 723744.

Hofmann, D. A., \& Morgeson, F. P. 1999. Safety-related behavior as a social exchange: The role of perceived organizational support and leader-member exchange. Journal of Applied Psychology, 84: 286-296.

Hollenbeck, J. R, Ilgen, D. R., \& Sego, D. J. 194. Repeated measures regression and mediational tests: Enhancing the power of leadership research. Leadership Quarterly, 5: 3-23.

Hom, P. W., Griffeth, R. W., Palich, L. E., \& Bracker, J. S. 1999. Revisiting met expectations as a reason why realistic job previews work. Personnel Psychology, 52: 97-112.

House, R. J., Shane, S. A., \& Herold, D. M. 1996. Rumors of the death of dispositional research are vastly exaggerated. Academy of Management Review, 21: 203-224.

Huselid, M. A. 1995. The impact of human resource management practices on turnover, productivity, and corporate financial performance. Academy of Management Journal, 38: 635-672.

Huselid, M. A., \& Becker, B. E. 2000. Comment on "measurement error in research on human resources and firm performance: How much error is there and how does it influence effect size estimates?" By Gerhart, Wright, McMahan, and Snell. Personnel Psychology, 53: 835-854.

Huselid, M. A., Jackson, S. E., \& Schuler, R. S. 1997. Technical and strategic human resource management effectiveness as determinants of firm performance. Academy of Management Journal, 40: 171-188.

Ichniowski, C., \& Shaw, K. 1999. The effects of human resource management systems on economic performance: An international comparison of U.S. and Japanese plants. Management Science, 45: 704-721.

Jenkins, G. D., Jr., Mitra, A., Gupta, N., \& Shaw, J. D. 1998. Are financial incentives related to performance? A meta-analytic review of empirical research. Journal of Applied Psychology, 83: 777-787. 
Judge, T. A., \& Bono, J. E. 2000. Five-factor model of personality and transformational leadership. Journal of Applied Psychology, 85: 751-765.

Judge, T. A., Bono, J. E., \& Locke, E. A. 2000. Personality and job satisfaction: The mediating role of job characteristics. Journal of Applied Psychology, 85: 237-249.

Judge, T. A., Higgins, C. A., Thoresen, C. J., \& Barrick, M. R. 1999. The big five personality traits, general mental ability, and career success across the life span. Personnel Psychology, 52: 621-652.

Keeping, L. M., \& Levy, P. E. 2000. Performance appraisal reaction: Measurement, modeling, and method bias. Journal of Applied Psychology, 85: 708-723.

Kerlinger, F. N. 1973. Foundations of Behavioral Research ( $2^{\text {nd }}$ Ed.), New York: Holt Rinehart and Winston, Inc.

Kerr, C. 1954. The Balkanization of labor markets. In E. W. Bakke, P. M. Hauser, G. L. Palmer, C. A. Myers, D. Yoder, \& C. Kerr (Eds.), Labor mobility and economic opportunity (pp. 93-109). New York: Wiley.

Kiker, D. S., \& Motowidlo, S. J. 1999. Main and interaction effects of task and contextual performance on supervisory reward decisions. Journal of Applied Psychology, 84: 602609.

Kirkman, B. L., \& Rosen, B. 1999. Beyond self-management: Antecedents and consequences of team empowerment. Academy of Management Journal, 42: 58-74.

Klein, H. J., \& Weaver, N. A. 2000. The effectiveness of an organizational-level orientation training program in the socialization of new hires. Personnel Psychology, 53: 47-66.

Koch, M. J., \& McGrath, R. G. 1996. Improving labor productivity: Human resource management policies do matter. Strategic Management Journal, 17: 335-354.

Kochan, T. 1999. Beyond Myopia: Human resources and the changing social contract. In P. Wright, L. Dyer, J. Boudreau, and G. Milkovich (eds) Research in Personnel and Human Resources Management, Supplement 4, pp.199-212 Greenwich, CT: JAI Press

Konrad, A. M., \& Mangel, R. 2000. The impact of work-life programs on firm productivity. Strategic Management Journal, 21: 1225-1237.

Koslowski, S.W.J. \& Klein, K. 2000. A multilevel approach to theory and research on organizations: Contextual, temporal, and emergent processes. In. K.J. Klein \& S.W.J. Kozlowski, (eds), Multilevel theory, research, and methods in organizations: Foundations, extensions, and new directions. (pp 3-90) San Francisco: Jossey-Bass Inc.

Kossek, E. \& Ozeki, C. 1998. Work-family conflict, policies, and the job-life satisfaction relationship: A review and directions for organizational behavior - human resource research. Journal of Applied Psychology, 83: 139-149.

Kristof-Brown, A.L. 2000. Perceived applicant fit: Distinguishing between recruiters' perceptions of person-job and person-organization fit. Personnel Psychology, 53: 643-671.

Lahteenmaki, S., Storey, J., Vanhala, S., 1998. HRM and company performance: The use of measurement and the influence of economic cycles. Human Resource Management Journal, 8: 51-65.

Lam, S. S. K., Hui, C., \& Law, K. S. 1999. Organizational citizenship behavior: Comparing perspectives of supervisors and subordinates across four international samples. Journal of Applied Psychology, 84: 594-601.

Lam, L. W., \& White, L. P. 1998. Human resource orientation and corporate performance. Human Resource Development Quarterly, 9: 351-64.

Lambert, S.J. 2000. Added benefits: The link between work-life benefits and organizational citizenship behavior. Academy of Management Journal, 43: 801-815.

Lawler, E. E. 1986. High-involvement management: Participative strategies for improving organizational performance. San Francisco, CA: Jossey-Bass.

Lee, M. B., \& Chee, Y. 1996. Business strategy, participative human resource management and organizational performance: The case of South Korea. Asia Pacific Journal of Human Resources, 34: 77-94 
Lee, C., \& Law, K. S., \& Bobko, P. 1999. The importance of justice perceptions on pay effectiveness: A two-year study of a skill-based pay plan. Journal of Management, 25: 851-873.

Lee, J., \& Miller, D. 1999. People matter: Commitment to employees, strategy and performance in Korean firms. Strategic Management Journal, 20: 579-593.

Lepak, D. P., \& Snell, S. A. 1999. The human resource architecture: Toward a theory of human capital allocation and development. Academy of Management Review, 24: 31-48.

Lepak, D.P., Takeuchi, R. \& Snell, S.A. In Press. An empirical examination of employment mode usage and firm performance. Journal of Management.

Lepine, J. A., Colquitt,J. A., \& Erez, A. 2000. Adaptability to changing task contexts: Effects of general cognitive ability, conscientiousness, and openness to experience. Personnel Psychology, 53: 563-593.

Locke, E. A., Alavi, M., \& Wagner, J. A. III. 1997. Participation in decision making: An information exchange perspective. In G. R. Ferris, et al. (Eds), Research in personnel and human resources management, 15: 293-331. Greenwich, CT: Jai Press, Inc.

Lynch, P. D., Eisenberger, R., \& Armeli, S. 1999. Perceived organizational support: Inferior versus superior performance by wary employees. Journal of Applied Psychology, 84: 467-483.

MacDuffie, J. P. 1995. Human Resource Bundles and Manufacturing Performance: Organizational Logic and Flexible Production Systems in the World Auto Industry. Industrial and Labor Relations Review, 48: 197-221.

Mahoney, T. A., \& Deckop, J. R. 1986. Evolution of concept and practice in personnel administration/human resource management (PA/HRM). Journal of Management, 12: 223-241.

Mathieu, J. E., Heffner, T. S., Goodwin, G. F., Salas, E., \& Cannon-Bowers, J. 2000. The influence of shared mental models on team process and performance. Journal of Applied Psychology, 85: 273-283.

Mayer, R. C., \& Davis, J. H. 1999. The effect of the performance appraisal system on trust for management: A field quasi-experiment. Journal of Applied Psychology, 84: 123-136.

McCormick, E. 1976. Job and task analysis. In M. D. Dunnette (Ed.), Handbook of industrial and organizational psychology, 651-696. Chicago: Rand McNally.

McMahan, G.C., Virick, M., \& Wright, P.M. 1999. Alternative theoretical perspectives for SHRM: Progress, Problems, and prospects. In Wright, P., Dyer, L., Boudreau, J., \& Milkovich, G. (Eds.). Research in Personnel and Human Resource Management (Supplement 4). Pp. 99-122. Greenwich, CT: JAI Press.

McManus, M. A., \& Kelly, M. L. 1999. Personality measures and biodata: Evidence regarding their incremental predictive value in the life insurance industry. Personnel Psychology, 52: 137-148.

Montemayor, E. F. 1996. Congruence between pay policy and competitive strategy in highperformance firms. Journal of Management, 22: 889-908.

Morrison, E. W., \& Phelps, C. C. 1999. Taking charge at work: Extrarole efforts to initiate workplace change. Academy of Management Journal, 42: 403-419.

Mount, M. K., Barrick, M. R., \& Strauss, J. P. 1999. The joint relationship of conscientiousness and ability with performance: Test of the interaction hypothesis. Journal of Management, 25: 707-721.

Mount, M. K., Witt, L. A., \& Barrick, M. R. 2000. Incremental validity of empirically keyed biodata scales over GMA and the five factor personality constructs. Personnel Psychology, 53: 299-323.

Moussa. F. M. 2000. Determinants, process, and consequences of personal goals and performance. Journal of Management, 26: 1259-1285.

Nease, A. A., Mudgett, B. O., \& Quinones, M. A. 1999. Relationships among feedback sign, self-efficacy, and acceptance of performance feedback. Journal of Applied Psychology, 84: 806-814. 
Neuman, G. A., \& Wright, J. 1999. Team effectiveness: Beyond skills and cognitive ability. Journal of Applied Psychology, 84: 376-389.

Ostroff, C. 2000. Human resource management and firm performance: Practices, systems, and contingencies. Working Paper, Arizona State University.

Ostroff, C. \& Bowen, D.E. 2000. Moving HR to a higher level: HR practices and organizational effectiveness. In K.J. Klein and S.W.J. Koslowski (Eds.) Multilevel theory, research, and methods in organizations.

Perry-Smith, J. E., \& Blum, T. C. 2000. Work-family human resource bundles and perceived organizational performance. Academy of Management Journal, 43: 1107-1117.

Phillips, J. M. 1998. Effects of realistic job previews on multiple organizational outcomes: A meta-analysis. Academy of Management Journal, 41: 673-690.

Porter, L. W., Pearce, J. L., Tripoli, A. M., \& Lewis, K. M. (1998). Differential perceptions of employers' inducements: Implications for psychological contracts. Journal of Organizational Behavior, 19: 769-782.

Pulakos, E. D., Arad, S., Donovan, M. A., \& Plamondon, K. E. 2000. Adaptability in the workplace: Development of a taxonomy of adaptive performance. Journal of Applied Psychology, 85: 612-624.

Richard, O.C., \& Johnson, N. 2001. Strategic human resource management effectiveness and firm performance. International Journal of Human Resource Management, 12: 299-310.

Roberson, Q. M., Moye, N. A., \& Locke, E. A. 1999. Identifying a missing link between participation and satisfaction: The mediating role of procedural justice perceptions. Journal of Applied Psychology, 84: 585-593.

Robinson, S. L., \& Rousseau, D. M. 1994. Violating the psychological contract: Not the exception but the norm. Journal of Organizational Behavior, 15: 245-259.

Rousseau, D. M., \& Greller, M. M. 1994. Human resource practices: Administrative contract makers. Human Resource Management, 33: 385-401.

Ryan, A. M., \& Ployhart, R. E. 2000. Applicants' perceptions of selection procedures and decisions: A critical review and agenda for the future. Journal of Management, 26: 565606.

Ryan, A. M., Ployhart, R. E., \& Friedel, L. A. 1998. Using personality testing to reduce adverse impact: A cautionary note. Journal of Applied Psychology, 83: 298-307.

Rynes, S. L., \& Bono, J. E. 2000. Psychological research on determinants of pay. In S. Rynes \& B. Gerhart (Eds.), Compensation in Organizations, 3-31. San Francisco, CA: JosseyBass Inc.

Sanchez, R. J., Truxillo, D. M., \& Bauer, T. N. 2000. Development and examination of an expectancy-based measure of test-taking motivation. Journal of Applied Psychology, 85: 739-750.

Schuler, R. S., \& Jackson, S. E. 1987. Linking competitive strategies with human resource management. Academy of Management Executive, 1: 207-219.

Scully, J. A., Kirkpatrick, S. A., \& Locke, E. A. 1995. Locus of knowledge as a determinant of the effects of participation on performance, affect, and perceptions. Organizational Behavior \& Human Decision Processes, 61: 276-288.

Seibert, S. E., \& Kraimer, M. L. 2001. The five-factor model of personality and career success. Journal of Vocational Behavior, 58: 1-21.

Shaw, J. D., Delery, J. E., Jenkins, G. D., \& Gupta, N. An organization-level analysis of voluntary and involuntary turnover. Academy of Management Journal, 41: 511-525.

Shaw, J. D., Duffy, M. K., \& Stark, E. M. 2000. Interdependence and preference for group work: Main and congruence effects on the satisfaction and performance of group members. Journal of Management, 26: 259-279.

Shaw, J. D., Gupta, N., \& Delery, J. 2001. Congruence between technology and compensation systems: Implications for strategy implementation. Strategic Management Journal, 22: 379-386. 
Shore, L. M., \& Barksdale, K. 1998. Examining degree of balance and level of obligation in the employment relationship: A social exchange approach. Journal of Organizational Behavior, 19: 731-744.

Simons, T., Pelled, L. H., \& Smith, K. A. 1999. Making use of difference: Diversity, debate, and decision comprehensiveness in top management teams. Academy of Management Journal, 42: 662-673.

Stevens, M. J., \& Campion, M. A. 1999. Staffing work teams: Development and validation of a selection test for teamwork settings. Journal of Management, 25: 207-228.

Sturman, M. C., \& Short, J. C. 2000. Lump-sum bonus satisfaction: Testing the construct validity of a new pay satisfaction dimension. Personnel Psychology, 53: 673-700.

Terpstra, D. E. \& Rozelle, E. J. 1993. The relationship of staffing practices to organizational level measures of performance. Personnel Psychology, 46: 27-48.

Tesluk, P. E., \& Mathieu, J. E. 1999. Overcoming roadblocks to effectiveness: Incorporating management of performance barriers into models of work group effectiveness. Journal of Applied Psychology, 84: 200-217.

Thomas, H. D. C., \& Anderson, N. 1998. Changes in newcomers' psychological contracts during organizational socialization: A study of recruits entering the British Army. Journal of Organizational Behavior, 19: 745-767.

Tsui, A. S., Pearce, J. L., Porter, L. W., \& Tripoli, A. M. 1997. Alternative approaches to the employee-organization relationship: Does investment in employees pay off? Academy of Management Journal, 40: 1089-1121.

Ulrich, D. 1998. Intellectual Capital = Competence X Commitment. Sloan Management Review, 39: 15-26.

Ulrich, D., \& Lake, D. 1991. Organizational capability: Creating competitive advantage. Academy of Management Executive, 5: 77-92.

Van Scotter, J., Motowidlo, S. J., \& Cross, T. C. 2000. Effects of task performance and contextual performance on systemic rewards. Journal of Applied Psychology, 85: 526535.

Viswesvaran, C., Ones, D.S., \& Schmidt, F.L. 1996. Comparative analysis of the reliability of job performance ratings. Journal of Applied Psychology, 81:557-574.

Walker, A. G., \& Smither, J. W. 1999. A five-year study of upward feedback: What managers do with their results matters. Personnel Psychology, 52: 393-423.

Wanberg, C. R., \& Banas, J. T. 2000. Predictors and outcomes of openness to changes in a reorganizing workplace. Journal of Applied Psychology, 85: 132-142.

Welbourne, T. M., \& Cyr, L. A. 1999. The human resource executive effect in initial public offering firms. Academy of Management Journal, 42: 616-629.

Welbourne, T. M., Johnson, D. E., \& Erez, A. 1998. The role-based performance scale: Validity analysis of a theory-based measure. Academy of Management Journal, 41: 540-555.

Whitener, E.M. 2001. Do "high commitment" human resource practices affect employee commitment? A cross-level analysis using hierarchical linear modeling. Journal of Management, 27: (will be out by the time this goes to edit).

Williams, J. R., Miller, C. E., Steelman, L. A., \& Levy, P. E. 1999. Increasing feedback seeking in public contexts: It takes two (or more) to tango. Journal of Applied Psychology, 84: 969-976.

Wood, R. E., Atkins, P. W. B., \& Bright, J. E. H. 1999. Bonuses, goals, and instrumentality effects. Journal of Applied Psychology, 84: 703-720.

Wright, P. M. 1998. HR fit: Does it really matter? Human Resource Planning, 21: 56-57.

Wright, P. M., Gardner, T. M., Moynihan, L. M., Park, H. J., Delery, J. R., \& Gerhart, B. 2001. Measurement error in research on human resources and firm performance: Additional data and suggestions for future research. Paper presented at the Academy of Management Meeting, Washington, D.C.

Wright, P. M., \& McMahan, G. C. 1992. Theoretical perspectives for strategic human resource management. Journal of Management, 18: 295-320. 
Wright, P. M., \& Sherman, W. S. 1999. Failing to find fit in strategic human resource management: Theoretical and empirical problems. In P. Wright, L. Dyer, B, J. Boudreau, and G. Milkovich, (Eds.), Strategic human resources management in the twenty-first century. Supplement 4 to G.R. Ferris (Ed.), Research in personnel and human resource management. Stanford, CT: JAI Press.

Wright, P.M. \& Snell, S. A. (1991). Toward an integrated view of strategic human resource management. Human Resource Management Review, 1, 203-225.

Wright, P. M., \& Snell, S. A. 1998. Toward a unifying framework for exploring fit and flexibility in strategic human resource management. Academy of Management Review, 23: 756-772. 